\title{
A Review on Applications of Ambient Assisted Living
}

\author{
Aneri M. Desai \\ Dept. of Information technology \\ SVM Institute of technology \\ Bharuch, India
}

\author{
Rutvij H. Jhaveri \\ Dept. of Computer Engineering \\ SVM Institute of technology \\ Bharuch, India
}

\begin{abstract}
The use of smart environments in the delivery of a pervasive care is the research topic that has witnessed increasing interest in recent years. These environments aim to deliver pervasive care through ubiquitous sensing by monitoring the occupant's activities of daily living. In order for these environments to succeed in achieving their goal, it is crucial that sensors deployed in the environments perform faultlessly. Ambient Assisted Living (AAL) is currently one of the important research and development areas, where accessibility, usability, and learning play a major role and where future interfaces are an important concern for applied engineering. In this paper, we discuss the research work carried out for various applications of AAL. We summarize techniques and tools for AAL and also their benefits and limitations. Using a summarized data we also look for different future challenges. The aim of this paper is to survey different AAL technologies to assist the elderly people to live in a smart environment.
\end{abstract}

\section{General Terms}

Internet-of-Things, Ambient Intelligence, Smart Environment

\section{Keywords}

Ambient Intelligence, Location Identification schemes, Mobile Robot, Smart Environment, Ambient Assisted Living.

\section{INTRODUCTION}

Over the years, the population of developed countries has increased and so, the people's life expectancy has also increased in the countries. The current demographic trends lead to an unbalanced life so it's creating a serious social challenge. Hence the task of maintaining and providing quality of services to the elderly people is one of themost important issues to be addressed.

Ambient Assisted Living (AAL) is nothing but products, services and methods which combine and develop new technologies and improves quality of life in all aspects. It is a platform which has begun to emerge to provide services elderly people in the world. In AAL, various products, services and methods transparently assist the daily living of people in need of support. This type of applicationsprovide an accurate localization of a people in indoor, outdoor and domestic environments which is one of the most important requirements of the people for living in a safe environment [1].AAL applications collect data through sensors and cameras and apply artificial intelligence for developing an intelligent system.
Ambient Intelligence (AMI) represents the future vision of intelligent computing where there exist several sensors and processors that are integrated with everyday objects to monitor daily activities of one's life.AMI is a new paradigm in computing technology which improving elderly people life to providing the smart environments that are self-organized, autonomous, sensitive, adaptive, and responsive to monitoring, analyzing human needs, behaviour, habits and emotions [2]. Using AMI with AAL, we can monitor the daily activities perform by people and support their lives by providing a smart environment.

Today we show the maximum use of computer technology which is best, reflected in the processors and tiny sensors that are being connected and processing with everyday objects. In recent years, there is maximum growth of mobile computing devices because of its mobility, which mainly include personal computers, smart phones, GPS, tablets, various sensors such as RFID tags, infrared motion sensors, as well as biometric identification sensors. Using such devices and sensors and adoption of services such as location services using a GPS has already sparked the realization of AMI [3].

As shown in figure 1 Cameras and sensors are connected with an AAL system or application through a wireless medium likes Wifi/Bluetooth/RFID. In AAL system these cameras and sensors are used for monitoring the activities in indoor home environment. After monitoring activities and based on that it analyse the behaviour of elderly people or a system. Using this behaviour and environment based reasoning with an AMI,creates an event. When events are created alarm trigger. Using alarm triggering it will decide that elderly needs a caretakers or not and if they needed it provides a care-taker and in some cases when expert advice is needed then it will give expert advice to the care-taker. This is how general AAL system can perform an operation.

Various organizations have developed different technologies of AAL for its verification and use in real world applications. Hence, researchers have focused on improvisation of AAL by addressing various design issues. In this paper, we will discuss recent research work and open challenges that would assist researchers to carry out further research on AAL. We also defined a limitation of recent research work carry out. Also defined how general AAL system can perform an operation. We defined different technologies area and different technologies of AAL which can be useful for the operation of AAL. 


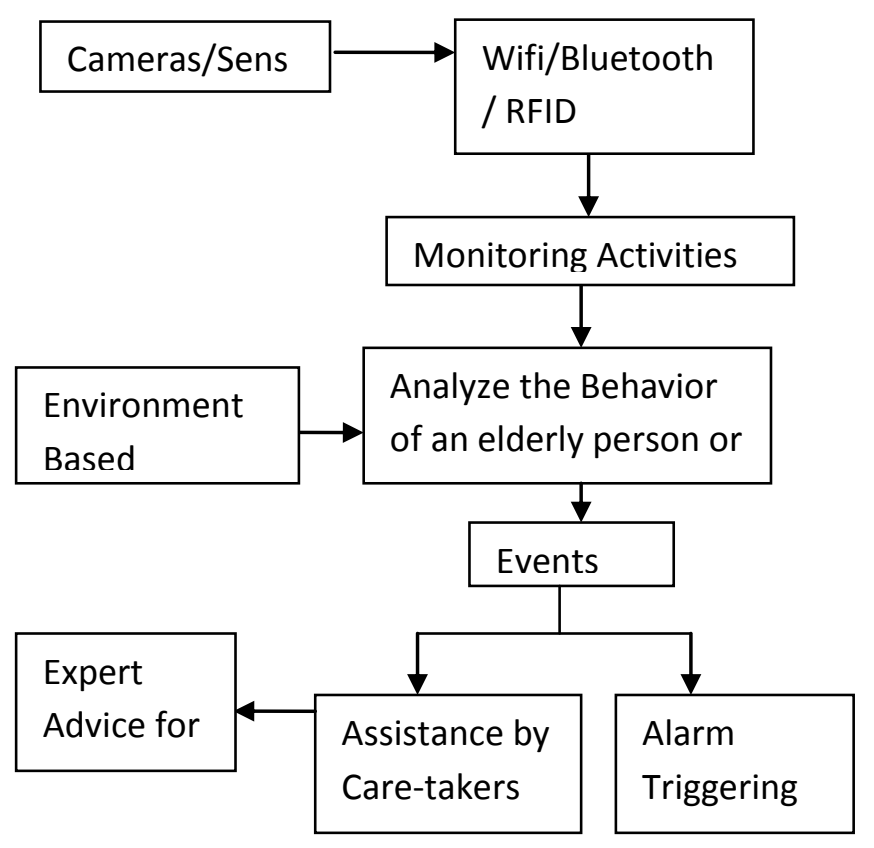

Fig 1: Operation of Ambient Assisted Living

The remainder of the paper is organized as follows. Section 2 contains an overview of AAL technology areas and distinct technologies. Section 3 surveys the recent research works carried out on AAL. Section 4 provides conclusions based on the study.

\section{THEORITICAL BACKGROUND}

In this paper, we discuss theoretical background about the work we carry out.

\subsection{AAL Technologies}

A several technological areas helped the vision of AAL such as smart homes, mobile and wearable sensors and assistive robotics [3].

\subsubsection{Smart Home}

A smart home is a regular home which has been augmented with various types of sensors and actuators where sensors provide a noise information and data. Because of that monitoring, analyzing, filtering and fusingvarious types of sensors data provide a rich context based information. For providing an autonomous, comfort and physical health to the resident, it utilizes knowledge with artificial intelligence. Smart Home uses sensors, cameras, wireless medium such as RFID, Wifi or Bluetooth for monitoring and identification of a person and his activities.

\subsubsection{Mobile and wearable Sensors}

Today, the mobility aspect of people is of prime importance because of the smart phones equipped with various sensors (such as an accelerometer, gyroscope, proximity sensor, and global positioning system (GPS)). This can be used for detecting user activity and mobility. Researchers have already developed non-invasive sensors in form of patches, small Holter-type devices, body-worn devices, and smart garments to monitor health signals.

\subsubsection{Assistive robots}

To overcome elderly people's physical limitations and to assist those in their daily activities assistive robot are used. Assistive robots help in various activities such as housekeeping, medication management, telephone use, shopping, laundry, feeding, grooming, bathing, dressing, and social communication.

\subsection{AAL Activities}

AAL supports a number of technologies such as activity recognition, context modeling, location identification, planning, and anomaly detection [3]

\subsubsection{Activity recognition}

To monitor and recognize the human activities smart cameras and sensors are used with intelligent applications for providing a smart environment. These are vital technologies where the activities represent a single movement, group activity, action.

\subsubsection{Context modeling}

AAL collects the data (low-level information) from different sources. To improve the information context modeling is used. Different types of Context information are sensor information, temporal information, medical history, spatial information and activities structure.

\subsubsection{Anomaly Detection}

Anomaly detection used for the problem of finding patterns in sensor-based data that do not conform to the expected behavior. Many anomaly detection techniques have been proposed in the literature such as clustering-based methods, statistical methods, and information theoretic methods.

\subsubsection{Location and Identity Identification}

To identify indoor and outdoor locations, is another important concern in AAL applications which allows tracking, monitoring and providing location-based services to the elderly. GPS has limited usage in indoor settings due to its limited accuracy and varying signal strengths.

\subsubsection{Planning}

Automatic planning and scheduling is another important component in many AAL systems. For instance, planning makes it possible to schedule daily plans and to create flexible daily reminders to help dementia patients to carry out their daily activities.

\section{RELATED WORK}

AAL plays an important role in demographic aging by providing an intelligent system to the elderly people. In recent years, many researchers have introduced different methods and protocols related to improving the quality of life using this system. Given below, shows the different methods and protocols which have been used to improve the quality of life. The same is summarized in Table 1.

Wilkie et al. [4] proposed a Sensor Anomaly Based Door State Detection technique which helps to explore the use of autonomous AAL with the help of mobile robots that uses anomalous sensor. This technique helps to facilitate selfhealing and self-configuration in a smart environment concerning detection of human traversal and door state detection.

Perakovic et al. [5] proposed a scheme which defines the quality of life of the people outside the basic environment. The aim of this scheme is to provide a safer environment to the society, especially to old age citizens. It is an ICT-based technology with AAL which proposes architecture of the traffic environment. Using this technique, we can locate the 
user in traffic environment and we can get more information when they move in the traffic.

Forkan et al. [6] proposed a scheme which provides heterogeneous services into a single model. It is a context model for AAL system which is easily modifiable, reusable, adaptable and extendable. It is a context-aware service management system with AAL environment using a cloud infrastructure. It provides service oriented architecture with context management system in cloud infrastructure.

Lloret et al. [7] a proposed system to provide smart communication architecture for AAL. This communication architecture with an artificial intelligence creates smart communication architecture. In this architecture, cameras and sensors are used to monitor various activities. To achieve the goal supervised intelligent system has been used that learns from user decisions and, caregivers and doctors for future cases.

Silva et al. [8] proposed a mobile based framework to improve the daily living conditions of old age people and reducing the burden of their caregivers. This AAL based solution supports older adults and care givers by providing mobile environments. For tracking elderly people in home environment, this technique uses fall detection, bio feed monitoring system, and outdoor location.

Trilles-Oliver et al. [9] proposed an indoor wi-fi fingerprint positioning system based on wearable devices and machine learning algorithms. It has two parts: the first is a mobile application which runs with an android wearable smart watch and second is the backend which uses positioning model based machine learning algorithms. An android based smart watch periodically measures wi-fi signal strengths and gives them to a server to estimate the current location of the user. A smartwatch is a perfect solution because of its characteristics such as portability and connection to the user when he moves around.

Bruno et al. [10] proposed a mechatronic system to provide autonomy to Bedridden Elderly People (BEP) to reduce the complexity of both older adults and caregivers. In this scheme, three conveyor layers are connected to the two centered motor, and each layer is supported by telescopic rails, so that it can easily enable bed-to-bed transfer.

Aintzane Armentia et al. [11] proposed a system architecture consisting of two parts called a domain model and multi-agent based middleware with AAL. This system provides a homecare application for elderly people. The domain's modeling approach defines the application from different point of views and gathers the relevant information. Multiagent based middleware converts the components into intelligent entities.

Dasios et al. [12] devised an experimental tested system by deploying a controller in the house with a wireless sensor network (WSN). It has nine modules in a house where each nine modules are used to collect environmental parameters and activity information of elderly people. It is Ubicare-based AAL system. This system uses activity detection, fall detection for helping older adults in a home.

Khali et al. [13] proposed a scheme which describes the pattern recognition models to detect behavior and healthrelated changes in a patient in AAL environment. In this scheme, hidden markov model approach is used for detecting an abnormal behavior. Abnormal behaviours are detected, and all the details are given to a fuzzy based system for a final guess which sends an accurate context-aware alert for a healthcare service provider.

Mario Marchese et al. [14] devised a communication architecture for Co-Morbidities Management which attempts to improve the coordination between the co-morbid patients and caregivers. It is a communication system to support AAL platforms for monitoring the patient's home. It is a smart phone centric architecture where smart phones are employed with sensing, processing and transmitting patient data to the devices.

Kun Wang et al. [15] proposed a Local Data Processing Architecture which can be used for local data processing and gathering, unlike ambient sensors. This architecture works on three parts that are data gathering, data filtering and data analyzing. It defines a risk factor, based on the local gathering of the data and defines the abnormal behavior of the system.

Tsirmpas et al. [16] proposed Self Organizing Maps (SOM) and Fuzzy C-Means (FCM) algorithms to provide the profile of user activities and their correlation with sensors. Here SOM is used for data mapping so that large data set are easily feasible. It also allows to map it into a multidimensional form of data for Internet of things (IoT). FCM provides a good result for an overlapped data set and allows a data point which may belong to more than one clusters. This scheme helps how components of IoT might collect data and be processed into contextual information.

Suciu et al. [17] proposed a scheme which helps a senior citizen with constant support from caregivers by monitoring his activities. In this scheme, both software and hardware based data are collected and monitored. For hardware based data, various sensor data are monitored using a cloud-based approach. For software-based data, the big data approach is used which collects information from various online sources and then fuses into a high level context information..

Konstantinidis et al. [18] proposed a Controller Application Communication (CAC) framework which can be used for multiple controller concurrently to connect to a number of devices as to oppose to a single device. It is based on distributed computing principles, where it encapsulates the controllers' data and reduces server's duties to use gateways. In this scheme, the definition is provided for integrating the hardware component of the system with multiple software components.

Rodrigues et al. [19] proposed a scheme which provides a solution for mobile environments. The scheme collects patients' data and avoids common risks. This collected data are stored in a smart phone using a bluetooth device. It is a bio feed monitoring system based on body sensors for collecting data to support remote monitoring for elderly people. It is a mobile healthcare solution in AAL environment to improve the life of older adults who live alone.

Lars Meinel et al. [20] Proposed scheme used for detecting and tracking multiple people to monitor complete room. In this scheme one single omnidirectional camera used for data collection and create virtual perspective of data using transformation of data .It is based on an omnidirectional camera and multiple objects tracking technique in AAL.

Nazemzadeh et al. [21] devised a Sensor Fusion with Kalman Filtering technique or indoor positioning tracking of moving users. It processes and fuses data from various sensors. It tracks the position of a system predicated by the Extended Kalman filter using the data sensor. 
Ruiz et al. [22] proposed a scheme which is based on sensors where force-capacitive transducer based sensors are used. It is an electromechanical film (EMFi) transducer which is able to detect force variations in a quasi-passive way. In this scheme, this transducer behaves like a capacitor to extend its surface. In this scheme, the user activities are monitored. When it detects an abnormal activity, an alert is triggered to the alarm system in the home.

Oskoei et al. [23] devised a multi robot architecture using AAL for elderly people which is based on robot operating system (ROS). The users interact with robot and smart home via human-machine interface (HMI). Robots perform various activities such as navigation, human-machine interaction, and multi-robot collaboration (based on autonomous behaviour). Moreover, an intelligent wheelchair is used for an autonomous navigation task to reach the goal position of the user in the environment map.

\section{CONCLUSIONS}

During this study, we discovered that most of the projects focus on a technical area, and not on user needs. Ambient Assisted Living (AAL) has now been a popular research area for researchers due to theirs applications in autonomous smart environment. On one side, their self-organizing and autonomous nature proves to be advantageous in many critical applications, on the other side it also raises several critical issues to be addressed such scalability, cost, time elapse, and battery of sensors, handling of multiple sensors data and many more. In this paper, we review different mechanisms which attempt to reduce the burden of old age people in their daily life activities. After analyzing various schemes, we conclude that different schemes work differently in distinct situations and each has its own limitations. A scheme may prove to be more advantageous than others in one situation, but may not reach to the expectations in other situation. At the same time, it is imperative to devise an ambient assisted living scheme which works well in various scenarios for all types of daily activities of peoples. This paper throws light on various aspects of ambient assisted living applications which can be helpful for researchers wishing to explore this area. We draw the conclusion that there is a big room for further research on AAL by incorporating effective machine learning algorithms.

\section{REFERENCES}

[1] A. Queirós, A. Silva, J. Alvarelhão, N. P. Rocha, and A. Teixeira, "Usability, accessibility and ambient-assisted living: a systematic literature review," Univers. Access Inf. Soc., vol. 14, no. 1, pp. 57-66, 2015.

[2] H. Daniell, "NIH Public Access," vol. 76, no. October 2009, pp. 211-220, 2012.

[3] P. Rashidi and A. Mihailidis, "A survey on ambientassisted living tools for older adults," IEEE J. Biomed. Heal. Informatics, vol. 17, no. 3, pp. 579-590, 2013.

[4] G. Brady, R. Sterritt, and G. Wilkie, "Mobile Robots and Autonomic Ambient Assisted Living," Paladyn, J. Behav. Robot., vol. 6, no. 1, pp. 205-217, 2015.

[5] T. Sciences, "Archives of Possibilities of implementing Ambient Assisted Living concept in," vol. 8, pp. 30-34, 2015.

[6] A. Forkan, I. Khalil, and Z. Tari, "CoCaMAAL: A cloudoriented context-aware middleware in ambient assisted living," Futur. Gener. Comput. Syst., vol. 35, pp. 114127, 2014.
[7] S. Sendra, L. Parra, J. Lloret, and A. Canovas, "A Smart Communication Architecture for Ambient Assisted Living," 2014 Int. Conf. Eng. Technol. Innov., no. January, pp. 1-7, 2015.

[8] B. M. C. Silva, J. J. P. C. Rodrigues, T. M. C. Simoes, S. Sendra, and J. Lloret, "An ambient assisted living framework for mobile environments," Biomed. Heal. Informatics (BHI), 2014 IEEE-EMBS Int. Conf., pp. 448-451, 2014.

[9] Ó. Belmonte-Fernández, A. Puertas-Cabedo, J. TorresSospedra, R. Montoliu-Colás, and S. Trilles-Oliver, "An indoor positioning system based on wearables for ambient-assisted living," Sensors (Switzerland), vol. 17, no. 1, pp. 1-22, 2017.

[10] S. Bruno, M. José, S. Filomena, C. Vítor, M. Demétrio, and B. Karolina, "The conceptual design of a mechatronic system to handle bedridden elderly individuals," Sensors (Switzerland), vol. 16, no. 5, pp. 111, 2016.

[11] A. Armentia, U. Gangoiti, R. Priego, E. Estévez, and M. Marcos, "Flexibility support for homecare applications based on models and multi-agent technology," Sensors (Switzerland), vol. 15, no. 12, pp. 31939-31964, 2015.

[12] A. Dasios, D. Gavalas, G. Pantziou, and C. Konstantopoulos, "Hands-on experiences in deploying cost-effective ambient-assisted living systems," Sensors (Switzerland), vol. 15, no. 6, pp. 14487-14512, 2015.

[13] A. R. M. Forkan, I. Khalil, Z. Tari, S. Foufou, and A. Bouras, "A context-aware approach for long-term behavioural change detection and abnormality prediction in ambient assisted living," Pattern Recognit., vol. 48, no. 3, pp. 628-641, 2015.

[14] I. Bisio, F. Lavagetto, M. Marchese, and A. Sciarrone, "Smartphone-centric ambient assisted living platform for patients suffering from co-morbidities monitoring," IEEE Commun. Mag., vol. 53, no. 1, pp. 34-41, 2015.

[15] K. Wang, Y. Shao, L. Shu, G. Han, and C. Zhu, "LDPA: A local data processing architecture in ambient assisted living communications," IEEE Commun. Mag., vol. 53, no. 1, pp. 56-63, 2015.

[16] C. Tsirmpas, A. Anastasiou, P. Bountris, and D. Koutsouris, "A New Method for Profile Generation in an Internet of Things Environment: An Application in Ambient-Assisted Living," IEEE Internet Things J., vol. 2, no. 6, pp. 471-478, 2015.

[17] G. Suciu, A. Vulpe, R. Craciunescu, C. Butca, and V. Suciu, "Big Data Fusion for eHealth and Ambient Assisted Living Cloud Applications,” pp. 102-106, 2015.

[18] E. I. Konstantinidis, P. E. Antoniou, G. Bamparopoulos, and P. D. Bamidis, "A lightweight framework for transparent cross platform communication of controller data in ambient assisted living environments," Inf. Sci. (Ny)., vol. 300, no. 1, pp. 124-139, 2015.

[19] D. F. M. Rodrigues, E. T. Horta, B. M. C. Silva, F. D. M. Guedes, and J. J. P. C. Rodrigues, "A mobile healthcare solution for ambient assisted living environments," 2014 IEEE 16th Int. Conf. e-Health Networking, Appl. Serv. Heal. 2014, pp. 170-175, 2015. 
[20] L. Meinel and M. Findeisen, "Automated real-time surveillance for ambient assisted living using an omnidirectional camera," ... (Icce), 2014 Ieee ..., pp. 402-405, 2014.

[21] P. Nazemzadeh, D. Fontanelli, and D. Macii, "An indoor position tracking technique based on data fusion for ambient assisted living," 2013 IEEE Int. Conf. Comput. Intell. Virtual Environ. Meas. Syst. Appl., pp. 7-12, 2013.

[22] F. J. Fernandez-Luque, F. L. Mart??nez, G. Dom??nech, J. Zapata, and R. Ruiz, "Ambient assisted living system with capacitive occupancy sensor," Expert Syst., vol. 31, no. 4, pp. 378-388, 2014.

[23] R. Li, M. A. Oskoei, and H. Hu, "Towards ROS based multi-robot architecture for ambient assisted living," Proc. - 2013 IEEE Int. Conf. Syst. Man, Cybern. SMC 2013, pp. 3458-3463, 2013.

6. APPENDIX

\begin{tabular}{|c|c|c|c|c|c|}
\hline Title & $\begin{array}{l}\text { Paper } \\
\text { Details }\end{array}$ & Methodology & Objective & Limitation & Future Scope \\
\hline $\begin{array}{l}\text { Mobile Robots and } \\
\text { Autonomic } \\
\text { Assisted Living }\end{array}$ & $\begin{array}{l}\text { George Wilkie et } \\
\text { al. De Gruyter } \\
\text { open (2015) [4] }\end{array}$ & $\begin{array}{l}\begin{array}{l}\text { Sensor Anomaly } \\
\text { Types, }\end{array} \\
\text { Door State Detection, } \\
\begin{array}{l}\text { Determining Human } \\
\text { Traversal }\end{array}\end{array}$ & $\begin{array}{l}\text { To explore the use of } \\
\text { Automatic Ambient Assisted } \\
\text { living using anomalous } \\
\text { sensor behaviour through the } \\
\text { utilization of a mobile robot. }\end{array}$ & $\begin{array}{l}\text { Identification of time } \\
\text { lapse that exists between } \\
\text { the occurrence of } \\
\text { anomalous sensor } \\
\text { behaviour and the robot } \\
\text { navigation to the site of } \\
\text { sensors }\end{array}$ & $\begin{array}{l}\text { Development of state } \\
\text { automation and their } \\
\text { capacity of adaptability } \\
\text { and scalability }\end{array}$ \\
\hline $\begin{array}{l}\text { Possibility of } \\
\text { implementing Ambient } \\
\text { Assisted Living concept in } \\
\text { traffic environment }\end{array}$ & $\begin{array}{l}\text { D.Perakovic et al. } \\
\text { Polish Association } \\
\text { of Transport } \\
\text { Telemetric(2014) } \\
{[5]}\end{array}$ & $\begin{array}{l}\text { AAL concept in traffic } \\
\text { environment }\end{array}$ & $\begin{array}{l}\text { To explore the capabilities of } \\
\text { individual technology } \\
\text { depending on the user's } \\
\text { needs and models of } \\
\text { establishing the possible } \\
\text { solution, using AAL in traffic } \\
\text { environment can contribute } \\
\text { to significant increase in the } \\
\text { quality of life in outside the } \\
\text { basic environment. }\end{array}$ & $\begin{array}{l}\text { In traffic environment it } \\
\text { depends on insufficient } \\
\text { financial means. }\end{array}$ & $\begin{array}{lrr}\text { Implement } & \text { public- } \\
\text { private form of } \\
\text { financing of all } \\
\text { possible solution }\end{array}$ \\
\hline $\begin{array}{l}\text { CoCaMAAL: Acloud - } \\
\text { oriented context-aware } \\
\text { middleware in ambient } \\
\text { assisted living }\end{array}$ & $\begin{array}{l}\text { Abdur Forkan et } \\
\text { al .Elsevier (2013) } \\
{[6]}\end{array}$ & $\begin{array}{l}\text { AAL application, } \\
\text { Context provider and } \\
\text { aggregator cloud }\end{array}$ & $\begin{array}{l}\text { To address and implement a } \\
\text { service oriented architecture } \\
\text { by using a context } \\
\text { management system and a } \\
\text { cloud based system with } \\
\text { sensor(s) }\end{array}$ & $\begin{array}{l}\text { Issue related to cost, } \\
\text { scalability, and support a } \\
\text { heterogeneous service } \\
\text { using a single model }\end{array}$ & $\begin{array}{l}\text { Noise reduction in } \\
\text { sensor data; solving } \\
\text { conflicts in context; } \\
\text { implementation of } \\
\text { security and privacy }\end{array}$ \\
\hline $\begin{array}{l}\text { A Smart Communication } \\
\text { Architecture for Ambient } \\
\text { Assisted Living }\end{array}$ & $\begin{array}{l}\text { Jaime Lloret et } \\
\text { al.IEEE (2015) [7] }\end{array}$ & $\begin{array}{l}\text { AAL application, } \\
\text { System Verification }\end{array}$ & $\begin{array}{l}\text { Smart communication } \\
\text { architecture for AAL using a } \\
\text { communication technology } \\
\text { detects elderly people needs. }\end{array}$ & $\begin{array}{l}\text { Life time of a system } \\
\text { based on consumption of } \\
\text { energy by a system }\end{array}$ & $\begin{array}{l}\text { Using robots } \\
\text { to assist better living } \\
\text { for elderly people }\end{array}$ \\
\hline $\begin{array}{l}\text { An Ambient Assisted } \\
\text { Living Framework for } \\
\text { Mobile Environments }\end{array}$ & $\begin{array}{l}\text { Bruno M.C.Silva } \\
\text { et al. IEEE (2014) } \\
{[8]}\end{array}$ & $\begin{array}{l}\text { Falls detection and } \\
\text { biofeedback } \\
\text { monitoring system, } \\
\begin{array}{l}\text { Outdoor location } \\
\text { system }\end{array}\end{array}$ & $\begin{array}{l}\text { To use mobile environment } \\
\text { to improve the quality of life } \\
\text { and health status of elderly } \\
\text { people without limitation on } \\
\text { their mobility }\end{array}$ & $\begin{array}{l}\text { Handling the mobility of } \\
\text { a user }\end{array}$ & $\begin{array}{l}\text { Integration of more } \\
\text { AAL tools for this } \\
\text { framework }\end{array}$ \\
\hline $\begin{array}{l}\text { An Indoor Positioning } \\
\text { System based on wearables } \\
\text { for Ambient - Assisted } \\
\text { Living }\end{array}$ & $\begin{array}{l}\text { Sergi Trilles- } \\
\text { Oliver et al. } \\
\text { Multidisciplinary } \\
\text { Digital publishing } \\
\text { Institute(2017) [9] }\end{array}$ & $\begin{array}{l}\text { Aware Indoor Loc } \\
\text { System Description, } \\
\text { Machine learning, } \\
\text { Message Queuing } \\
\text { Telemetry Transport } \\
\text { connectivity protocol }\end{array}$ & $\begin{array}{l}\text { To track the current location } \\
\text { of the user as he moves along } \\
\text { home }\end{array}$ & $\begin{array}{l}\text { Problem with battery life } \\
\text { of a system }\end{array}$ & $\begin{array}{l}\text { Implementing } \text { the } \\
\text { system for outdoor } \\
\text { environment }\end{array}$ \\
\hline $\begin{array}{l}\text { The Conceptual Design of } \\
\text { a Mechatronic System to } \\
\text { Handle Bedridden Elderly } \\
\text { Individuals }\end{array}$ & $\begin{array}{l}\text { Silva Bruno et } \\
\text { al.Multidisciplinar } \\
\text { y Digital } \\
\text { Publishing } \\
\text { Institute } \\
\end{array}$ & $\begin{array}{lr}\text { Custom } & \text { drive } \\
\text { mechanism } & \text { using } \\
\text { crossed } & \text { tensioned } \\
\text { elements, } & \\
\end{array}$ & $\begin{array}{l}\text { To provide autonomy of } \\
\text { movement and improve the } \\
\text { quality of life of elderly } \\
\text { people }\end{array}$ & $\begin{array}{lr}\text { Issues regarding } & \text { legal } \\
\text { authorizations } & \text { for } \\
\text { performing live test } & \end{array}$ & $\begin{array}{l}\text { New devices and } \\
\text { applications r for } \\
\text { improving the quality } \\
\text { of life }\end{array}$ \\
\hline
\end{tabular}




\begin{tabular}{|c|c|c|c|c|c|}
\hline & {$[10]$} & $\begin{array}{l}\text { load presence } \\
\text { detection, } \\
\text { bed detection sensor }\end{array}$ & & & \\
\hline $\begin{array}{l}\text { Flexibility Support for } \\
\text { Homecare Applications } \\
\text { Based on Models and } \\
\text { Multi-Agent Technology }\end{array}$ & $\begin{array}{l}\text { Aintzane } \\
\text { Armentia et } \\
\text { al.Multidisciplinar } \\
\text { y Digital } \\
\text { Publishing } \\
\text { Institute(2015) } \\
\text { [11] }\end{array}$ & $\begin{array}{lr}\text { Domain } & \text { Modelling } \\
\text { Approach } & \text { for } \\
\text { Application } & \\
\text { Specification } & \text { and } \\
\text { multiple agent } & \text { based } \\
\text { middleware (MAS- } & \text { RECON Middleware) }\end{array}$ & $\begin{array}{l}\text { To negotiation } \\
\text { capabilities of agent to } \\
\text { support the flexibility of } \\
\text { application and fault } \\
\text { tolerance }\end{array}$ & $\begin{array}{l}\text { Problem with } \\
\text { adaptability, availability } \\
\text { and identification of the } \\
\text { needs of the target } \\
\text { application }\end{array}$ & $\begin{array}{l}\text { Distribution of the } \\
\text { system to improve the } \\
\text { fault tolerance of the } \\
\text { middleware modules } \\
\text { and implementing the } \\
\text { admission control }\end{array}$ \\
\hline $\begin{array}{l}\text { Hands-On Experiences in } \\
\text { Deploying Cost-Effective } \\
\text { Ambient -Assisted Living } \\
\text { Systems }\end{array}$ & $\begin{array}{l}\text { Athanasios Dasios } \\
\text { et al. } \\
\text { Multidisciplinary } \\
\text { Digital Publishing } \\
\text { Institute (2015) } \\
{[12]}\end{array}$ & $\begin{array}{lr}\text { Experimental } & \text { Tested } \\
\text { Architecture } & \text { of } \\
\text { Ubicare } & \end{array}$ & $\begin{array}{l}\text { To support activity detection, } \\
\text { fall detection and well-being } \\
\text { promotion for elderly people }\end{array}$ & $\begin{array}{l}\text { Automated alarms which } \\
\text { may be forwarded to } \\
\text { authorized caregivers via } \\
\text { variety of } \\
\text { communication channels }\end{array}$ & $\begin{array}{l}\text { Prototype extension for } \\
\text { air quality monitoring } \\
\text { to detect fire or high } \\
\text { concentration of carbon } \\
\text { monoxide or automated } \\
\text { control of air quality } \\
\text { and cleaning devices }\end{array}$ \\
\hline $\begin{array}{l}\text { A Context -aware approach } \\
\text { for long-term behavioural } \\
\text { change detection and } \\
\text { abnormality prediction in } \\
\text { ambient assisted living }\end{array}$ & $\begin{array}{l}\text { Ibrahim khali et } \\
\text { al. ELSEVIER } \\
(2015) \text { [13] }\end{array}$ & $\begin{array}{l}\text { Hidden Markov } \\
\text { Model, } \\
\text { Decision making using } \\
\text { Fuzzy rules }\end{array}$ & $\begin{array}{l}\text { To detect behavioural and } \\
\text { health-related changes in } \\
\text { patients }\end{array}$ & $\begin{array}{l}\text { It predicts value on } \\
\text { knowledge which is not } \\
\text { an accurate method }\end{array}$ & $\begin{array}{l}\text { Extending context } \\
\text { domains such as social } \\
\text { interaction }\end{array}$ \\
\hline $\begin{array}{l}\text { Smartphone- } r \text { Centric } \\
\text { Ambient Assisted Living } \\
\text { platform for Patients } \\
\text { Suffering from Co- } \\
\text { Morbidities Monitoring. }\end{array}$ & $\begin{array}{l}\text { Mario Marchese } \\
\text { et al.IEEE (2015) } \\
\text { [14] }\end{array}$ & $\begin{array}{l}\text { Communication } \\
\text { Architecture for Co- } \\
\text { Morbidities } \\
\text { management, } \\
\text { Smartphone-Centric } \\
\text { Solution for E-Health } \\
\text { Application }\end{array}$ & $\begin{array}{l}\text { To monitor patients suffering } \\
\text { from a set of physical and } \\
\text { mental limitation called Co- } \\
\text { Morbidities using a } \\
\text { Smartphone Centric AAL }\end{array}$ & $\begin{array}{l}\text { High consumption of } \\
\text { time to monitor location, } \\
\text { and to communicate for } \\
\text { health care }\end{array}$ & $\begin{array}{l}\text { Using a robot } \\
\text { navigation based on } \\
\text { smart phones }\end{array}$ \\
\hline $\begin{array}{l}\text { LDPA:A Local Data } \\
\text { Processing Architecture in } \\
\text { Ambient Assisted Living } \\
\text { Communications }\end{array}$ & $\begin{array}{l}\text { Kun Wang et } \\
\text { al.IEEE(2015) } \\
{[15]}\end{array}$ & $\begin{array}{l}\text { Reduced Variable } \\
\text { Neighbourhood } \\
\text { Search(RVNS) } \\
\text { Algorithm, } \\
\text { Local Data Processing } \\
\text { Architecture }\end{array}$ & $\begin{array}{l}\text { To address the problem of } \\
\text { rapid analysis and processing } \\
\text { a massive data }\end{array}$ & $\begin{array}{l}\text { Problem of transferring } \\
\text { local data for the central } \\
\text { processing }\end{array}$ & $\begin{array}{lr}\text { Designing a risk } \\
\text { function under different } \\
\text { scenarios and } \\
\text { simplifying the risk } \\
\text { function for accuracy }\end{array}$ \\
\hline $\begin{array}{l}\text { A new method for profile } \\
\text { generation in an Internet of } \\
\text { Things environment: An } \\
\text { application in ambient } \\
\text { assisted living. }\end{array}$ & $\begin{array}{l}\text { C.Tsirmpas et al. } \\
\text { IEEE (2015) [16] }\end{array}$ & $\begin{array}{l}\text { Self Organizing } \\
\text { Maps(SOM), } \\
\text { Fuzzy C-Means(FCM) } \\
\text { algorithm }\end{array}$ & $\begin{array}{l}\text { To collect data for processing } \\
\text { them into contextual } \\
\text { information }\end{array}$ & $\begin{array}{l}\text { Converting a low }- \text { level } \\
\text { information collected } \\
\text { from different sources } \\
\text { into a contextual } \\
\text { information }\end{array}$ & 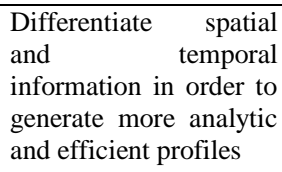 \\
\hline $\begin{array}{l}\text { Big Data Fusion for } \\
\text { ehealth and Ambient } \\
\text { Assisted Living Cloud } \\
\text { Applications }\end{array}$ & $\begin{array}{l}\text { George Suciu et } \\
\text { al. IEEE (2015) } \\
{[17]}\end{array}$ & $\begin{array}{l}\text { Data source and Data } \\
\text { Fusion, } \\
\begin{array}{l}\text { Fusion Method for } \\
\text { correlated data }\end{array}\end{array}$ & $\begin{array}{l}\text { To monitor the healthcare } \\
\text { condition of senior citizens } \\
\text { and to fuse big data from } \\
\text { various information flows } \\
\text { coming from sensors }\end{array}$ & $\begin{array}{l}\text { Particles filter is major } \\
\text { limitation of fusion } \\
\text { correlated method }\end{array}$ & $\begin{array}{l}\text { Adding data sources } \\
\text { from social network in } \\
\text { order to enable other } \\
\text { cloud applications such } \\
\text { as games and unified } \\
\text { communications }\end{array}$ \\
\hline $\begin{array}{l}\text { A lightweight framework } \\
\text { for transparent cross } \\
\text { platform communication of } \\
\text { controller data in ambient } \\
\text { assisted living } \\
\text { environments }\end{array}$ & $\begin{array}{l}\text { Evdokimos I. } \\
\text { Konstantinidis et } \\
\text { al. ELSEVIER } \\
(2015)[18]\end{array}$ & $\begin{array}{l}\text { Controller Application } \\
\text { Communication } \\
\text { (CAC)Framework, } \\
\text { CAC Architecture }\end{array}$ & $\begin{array}{l}\text { To concurrently use } \\
\text { sensors/controller devices by } \\
\text { different application of AAL, } \\
\text { especially health care } \\
\text { monitoring for elderly }\end{array}$ & $\begin{array}{l}\text { Handling } \\
\text { sensors data }\end{array}$ & $\begin{array}{l}\text { Designing frameworks } \\
\text { to facilitate more } \\
\text { diverse controller set } \\
\text { and allow on-demand } \\
\text { online data streaming }\end{array}$ \\
\hline $\begin{array}{lr}\text { A Mobile } & \text { Healthcare } \\
\text { Solution for } & \text { Ambient } \\
\text { Assisted } & \text { Living } \\
\text { Environment } & \end{array}$ & $\begin{array}{l}\text { Daniel } \\
\text { F.M.Rodrigues et } \\
\text { al.IEEE (2014) } \\
{[19]}\end{array}$ & $\begin{array}{l}\text { Mobile wearable } \\
\text { sensor architecture }\end{array}$ & $\begin{array}{l}\text { To design mobile healthcare } \\
\text { solution for AAL } \\
\text { environment that improves } \\
\text { the lives of lonely elderly } \\
\text { people }\end{array}$ & $\begin{array}{l}\text { Handling multi-agent } \\
\text { system }\end{array}$ & $\begin{array}{l}\text { Deployment of two or } \\
\text { more types of sensors } \\
\text { to analyse the patient } \\
\text { posture }\end{array}$ \\
\hline $\begin{array}{l}\text { Automated Real-Time } \\
\text { Surveillance for Ambient } \\
\text { Assisted Living using an }\end{array}$ & $\begin{array}{l}\text { Lars Meinel et al. } \\
\text { IEEE (2014) [20] }\end{array}$ & $\begin{array}{l}\text { Multiple } \\
\text { tracking }\end{array}$ & $\begin{array}{l}\text { To detect and track multiple } \\
\text { persons in order to monitor a }\end{array}$ & $\begin{array}{l}\text { Using an omnidirectional } \\
\text { camera and transforming }\end{array}$ & $\begin{array}{l}\text { Developing } \\
\text { algorithm for parallel } \\
\text { architecture and also }\end{array}$ \\
\hline
\end{tabular}




\begin{tabular}{|c|c|c|c|c|c|}
\hline Omnidirectional Camera & & transformation & complete room & data is difficult & $\begin{array}{lr}\text { multi-room } & \text { indoor } \\
\text { surveillance } & \text { system } \\
\text { based on smart } & \text { sensor } \\
\text { network } & \end{array}$ \\
\hline $\begin{array}{l}\text { An Indoor positioning } \\
\text { Tracking Technique based } \\
\text { on Data Fusion for } \\
\text { Ambient Assisted Living. }\end{array}$ & $\begin{array}{l}\text { Payam } \\
\text { Nazemzadeh et } \\
\text { al.IEEE (2013) } \\
{[21]}\end{array}$ & $\begin{array}{ll}\text { Sensor Fusion } & \text { with } \\
\text { Kalman Filtering } & \end{array}$ & $\begin{array}{l}\text { To track the position of a } \\
\text { smart rotator and estimate the } \\
\text { errors of impaired people } \\
\text { moving in large indoor } \\
\text { environments }\end{array}$ & $\begin{array}{lr}\begin{array}{l}\text { Implementing } \\
\text { position }\end{array} & \text { real-time } \\
\text { tracking } \\
\text { capabilities }\end{array}$ & $\begin{array}{l}\text { Improving accuracy } \\
\text { and cost }\end{array}$ \\
\hline $\begin{array}{l}\text { Ambient assisted living } \\
\text { System with capacitive } \\
\text { occupancy sensor. }\end{array}$ & $\begin{array}{l}\text { Ramon Ruiz et al. } \\
\text { Wiley (2013) [22] }\end{array}$ & $\begin{array}{l}\text { Electromechanical } \\
\text { film (EMFI) based } \\
\text { sensor }\end{array}$ & $\begin{array}{l}\text { To improve the result of } \\
\text { AAL using an occupancy } \\
\text { sensor to improve energy } \\
\text { consumption }\end{array}$ & $\begin{array}{l}\text { Modelling a transducer } \\
\text { as a variable capacitor } \\
\text { whose capacitance } \\
\text { depends on the static } \\
\text { force }\end{array}$ & $\begin{array}{l}\text { Reducing cost and } \\
\text { energy consumption }\end{array}$ \\
\hline $\begin{array}{l}\text { Towards ROS based Multi- } \\
\text { Robot Architecture for } \\
\text { Ambient Assisted Living }\end{array}$ & $\begin{array}{l}\text { Mohammadreza } \\
\text { A.Oskoei et al. } \\
\text { IEEE (2013) [23] }\end{array}$ & $\begin{array}{l}\text { Smart environment } \\
\text { with multiple service } \\
\text { Robots }\end{array}$ & $\begin{array}{l}\text { To provide autonomous } \\
\text { navigation, human machine } \\
\text { interaction and multi robot } \\
\text { communication in healthcare } \\
\text { for elderly people }\end{array}$ & $\begin{array}{l}\text { Moving a wheel-chair at } \\
\text { door places using } \\
\text { autonomous navigation }\end{array}$ & $\begin{array}{lr}\text { Developing } & \text { human- } \\
\text { machine interface } \\
\text { based voice dialog } \\
\text { system and gesture } \\
\text { controller }\end{array}$ \\
\hline
\end{tabular}

